\title{
Alktivitas Antibakteri Ekstrak Etanol Daun Sesewanua (Clerodendron Squamatum Vahl.) terhadap Bakteri Staphylococcus aureus, Escherichia coli, dan Salmonella typhi
}

\author{
Vanesa Vebiola Kumakauw ${ }^{a^{*}}$,Herny Emma Inonta Simbalaa, Karla Lifie Riani \\ Mansaudaa \\ aProgram Studi Farmasi, Fakultas MIPA, Universitas Sam Ratulangi, Manado, \\ Indonesia
}

KATA KUNCI

Aktivitas antibakteri,

Sesewanua, bakteri patogen, metode difusi Kirby dan Bauer
KE Y W O R D S

Antibacterial activity, Sesewanua, pathogen bacterial, Kirby and bauer difussion method

\begin{abstract}
A B S T R A K
Sesewanua (Clerodendron squamatum Vahl.) secara empiris telah digunakan oleh masyarakat dibeberapa daerah di Sulawesi Utara untuk mengobati berbagai macam penyakit. Penelitian ini bertujuan untuk mengetahui aktivitas antibakteri dari ekstrak etanol daun sesewanua terhadap daya hambat pertumbuhan bakteri Staphylococcus aureus, Escherichia coli dan Salmonella typhi menggunakan tiga kosentrasi yakni 20\%, 40\% dan 60\%. Ekstraksi dilakukan dengan cara maserasi menggunakan etanol 96\%. Pengujian aktivitas antibakteri menggunakan metode difusi dengan cakram kertas (difusi Kirby dan Bauer). Hasil penelitian ini menunjukkan bahwa ekstrak etanol daun sesewanua berpotensi sebagai antibakteri dan memiliki kekuatan antibakteri terhadap Staphylococcus aureus, Escherichia coli dan Salmonella typhi, pada kosentrasi 20\%, 40\% dan 60\% termasuk golongan kuat untuk menghambat bakteri Staphylococcus aureus, sedangkan pada kosentrasi $40 \%$ dan $60 \%$ termasuk dalam golongan kuat untuk menghambat bakteri Escherichia coli dan Salmonella typhi.
\end{abstract}

A B S T R A C T

Sesewanua (Clerodendron squamatum Vahl.) have been used by communities in North Sulawesi for to treat or handle various diseases. This study aims to determine the antibacterial activity from ethanol extract Sesewanua Leaves against the growth inhibition of the bacterium Staphylococcus aureus, Escherichia coli and Salmonella typhi using three concentrations of $20 \%, 40 \%$ and $60 \%$. Extraction was done by maceration method using ethanol $96 \%$. Antibacterial activity test was performing using the paper disk diffusion method (Kirby and Bauer diffusion). This results of this study indicate that ethanol extracts of Sesewanua leaves are considered as antibacterial and have antibacterial strength against Staphylococcus aureus, Escherichia coli and Salmonella typhi, at concentrations of $20 \%, 40 \%$ and $60 \%$ include strong groups to inhibit Staphylococcus aureus, while at a concentration of $40 \%$ and $60 \%$ include strong groups to inhibit Escherichia coli and Salmonella typhi.

TERSEDIA ONLINE

01 Agustus 2020

\section{Pendahuluan}

Penyakit infeksi masih merupakan jenis penyakit yang paling banyak diderita oleh penduduk di negara berkembang, termasuk Indonesia. Salah satu penyebab penyakit infeksi adalah bakteri.
Bakteri merupakan mikroorganisme yang tidak dapat dilihat dengan mata telanjang, tetapi hanya dapat dilihat dengan bantuan mikroskop (Radji, 2011).

Penggunaan obat antibakteri untuk pengobatan penyakit infeksi yang disebabkan oleh bakteri sekarang sudah cukup banyak, namun masalah 
yang dihadapi sekarang adalah terjadinya efek samping bagi penggunanya, seperti diare, alergi, hingga bahaya toksik lainnya, serta konsumsi biaya perawatan yang tinggi (Brooks, 2013). Banyaknya kasus infeksi akibat bakteri, timbulnya efek samping penggunaan obat antibakteri, serta konsumsi biaya perawatan yang tinggi menunjukkan perlu dilakukannya penelitian untuk mengembangkan antibakteri baru khususnya dari bahan alam.

Sesewanua (Clerodendron squamatum Vahl.) secara empiris telah digunakan oleh masyarakat dibeberapa daerah di Sulawesi Utara untuk mengobati berbagai macam penyakit seperti demam, patah tulang, menghilangkan nyeri dan penurunan bengkak, senyawa yang diduga bersifat sebagai antipiretik dalam infusa daun sesewanua ialah flavonoid (Moot et al. 2013). Menurut Sangi et al. (2008) daun sesewanua dianalisis mengandung alkaloid dan flavonoid. Menurut Huliselan et al. (2015) ekstrak etil asetat daun sesewanua mengandung senyawa antioksidan yang tinggi dengan menggunakan metode 1,1-difenil-2pikrilhidrazil (DPPH). Menurut Yudistira (2017) ekstrak etanol daun sesewanua memiliki aktivitas antikanker yang sedang. Menurut Patel et al. (2014) tanaman genus Clerodendron mengandung senyawa antibakteri terhadap bakteri Staphylococcus aureus, Bacillus subtilis, Escherichia coli, Pseudomonas aeruginosa.

Berdasarkan hal tersebut maka peneliti tertarik untuk melakukan penelitian mengenai aktivitas ekstrak etanol daun Sesewanua (Clerodendron squamatum Vahl.) yang diekstraksi dengan pelarut etanol dalam menghambat pertumbuhan bakteri Staphylococcus aureus, Escherichia coli, dan Salmonella typhi.

\section{Material dan Metode}

\section{Waktu dan Tempat Penelitian}

Penelitian ini di laksanakan pada bulan November 2019 - Januari 2020, di Laboratorium Farmasi Lanjut Program Studi Farmasi Fakultas Matematika dan IImu Pengetahuan Alam.

\section{Jenis Penelitian}

Penelitian ini merupakan penelitian dengan menggunakan metode eksperimental Laboratorium yang akan menguji aktivitas antibakteri ekstrak etanol daun Sesewanua (Clerodendron squamatum Vahl.) terhadap bakteri Staphylococcus aureus, Escherichia coli dan Salmonella typhi.

\section{Alat dan Bahan}

Alat-alat yang digunakan antara lain aluminium foil, ayakan, labu ekstraksi, timbangan analitik, wadah ekstrak, erlenmeyer, jarum ose,lampu Bunsen, pemanas air, cawan petri, tabung reaksi, rak tabung reaksi, gelas ukur, pipet tetes, autoklaf, inkubator, lemari pendingin, kertas saring, mikro pipet, mistar berskala, laminar air flow, batang pengaduk, pinset, alat fotografi, dan alat-alat gelas lainnya.

Bahan-bahan yang digunakan yaitu ekstrak daun Sesewanua (Clerodendron squamatum Vahl.), bakteri uji Staphylococcus aureus, Escherichia coli dan Salmonella typhi, aquades, etanol 96\%, nutrient agar (NA), ciprofloxacin, $\mathrm{H} 2 \mathrm{SO} 4, \mathrm{BaCl} 22 \mathrm{H} 2 \mathrm{O}$ 1,175\% dan $\mathrm{NaCl} 0,9 \%$.

\section{Pengambilan dan Persiapan Sampel}

Sampel yang digunakan pada penelitian ini yaitu daun Sesewanua (Clerodendron squamatum Vahl.)), yang diambil di Kecamatan Kakas Barat, Kab. Minahasa.

Daun Sesewanua (Clerodendron squamatum Vahl.) yang telah dikumpulkan dibersihkan dari kotoran, selanjutnya dicuci dengan air sampai bersih, ditiriskan, lalu dikeringkan dengan cara dianginanginkan. Sampel yang telah kering diserbukkan dengan menggunakan blender, serbuk yang dihasilkan diayak menggunakan ayakan mesh 65 hingga diperoleh serbuk yang halus. Hasilnya dimasukkan ke dalam wadah gelas tertutup.

\section{Identifikasi Tumbuhan}

Identifikasi tanaman dilakukan di Bagian Taksonomi Tumbuhan Program Studi Biologi Fakultas Matematika dan IImu Pengetahuan Alam, Universitas Sam Ratulangi Manado.

\section{Ekstraksi sampel}

Ekstraksi dilakukan dengan metode maserasi menggunakan pelarut etanol 96\%. Serbuk daun Sesewanua (Clerodendron squamatum Vahl.) ditimbang sebanyak 300 gram dan dimasukkan ke dalam wadah, kemudian ditambahkan pelarut etanol 96\% sebanyak $900 \mathrm{~mL}$ dengan perbandingan 1:3 selama 5 hari dengan sesekali diaduk. Hasil maserasi kemudian disaring dengan kertas saring sehingga dihasilkan filtrat 1 dan residu 1 . Residu yang diperoleh kemudian ditambahkan lagi pelarut etanol $96 \%$ sebanyak $900 \mathrm{~mL}$ dengan perbandingan yang sama 1 : 3 selama 3 hari dengan sesekali diaduk. Hasil maserasi kemudian disaring dengan kertas saring sehingga dihasilkan filtrat 2 dan residu Residu yang diperoleh ditambahkan pelarut etanol 96\% sebanyak $900 \mathrm{~mL}$ dengan perbandingan 1: 3 selama 3 hari dengan sesekali diaduk. Hasil maserasi kemudian disaring dengan kertas saring sehingga dihasilkan filtrat 3 dan residu 3 . Perendaman dengan pelarut etanol 96\% dilakukan 3 kali maserasi dengan jenis dan jumlah pelarut yang sama. Filtrat 1, 2 dan 3 yang diperoleh kemudian dicampur menjadi satu dan dipekatkan dengan oven pada suhu $40^{\circ} \mathrm{C}$ hingga diperoleh ekstrak kental.

\section{Sterilisasi Alat}

Alat - alat yang digunakan dalam penelitian uji aktivitas antibakteri ini disterilkan dalam autoklaf pada suhu $121^{\circ} \mathrm{C}$ selama 15 menit (Lay, 1994).

\section{Pembuatan Larutan Kontrol Positif}

Larutan kontrol positif dibuat dari sediaan obat tablet Ciprofloxacin 500 mg. Satu tablet Ciprofloxacin digerus lalu ditimbang 0,05 g, kemudian dilarutkan dalam $50 \mathrm{ml}$ CMC. Diambil 1 $\mathrm{mL}$ dari larutan tersebut dan ditambahkan CMC sampai $10 \mathrm{~mL}$, sehingga diperoleh larutan Ciprofloxacin dengan konsentrasi 50 $\mathrm{g} / 50 \mu \mathrm{l}$. Konsentrasi ini digunakan sebagai kontrol positif 
(Vandepitte et al., 2005).

\section{Pembuatan Larutan Kontrol Negatif}

Kontrol negatif dibuat dari CMC 1\% dengan cara

: 1 gram serbuk CMC dilarutkan dalam $100 \mathrm{ml}$ aquades steril. Dikocok sampai larutan homogen. Kontrol negatif digunakan sebagai pembanding dan pelarut untuk pembuatan Iarutan uji.

\section{Pembuatan Larutan Uji}

Dari larutan uji 20\%, 40\%, 60\% dengan cara ditimbang 0,2 g, 0,4 g, 0,6 g, ekstrak etanol daun sesewanua kemudian masing-masing dilarutkan dalam $1 \mathrm{~mL}$ CMC.

\section{Pembuatan Media}

\section{a. Pembuatan Media Agar Miring}

Nutrient Agar (NA) sebanyak 0,4 gram dilarutkan dalam $20 \mathrm{~mL}$ aquades (20 g / $1000 \mathrm{~mL}$ ) menggunakan Erlenmeyer. Larutan dihomogenkan dengan stirrer diatas penangas air sampai mendidih. Sebanyak $5 \mathrm{~mL}$ dituangkan masingmasing pada 2 tabung reaksi steril dan ditutup dengan aluminium foil. Media tersebut disterilkan dalam autoklaf pada suhu $121^{\circ} \mathrm{C}$ selama 15 menit, kemudian dibiarkan pada suhu ruangan selama \pm 30 menit sampai media memadat pada kemiringan $30^{\circ}$. Media Agar miring digunakan untuk inokulasi bakteri (Lay, 1994).

\section{b. Pembuatan Media Pengujian}

Media dasar dibuat dengan cara ditimbang Nutrient Agar (NA) sebanyak 5,6 g, lalu dilarutkan dalam $200 \mathrm{~mL}$ akuades menggunakan erlenmeyer. Media dihomogenkan dengan stirer diatas penangas air sampai mendidih. Media yang sudah homogen ini disterilkan dalam autoklaf pada suhu $121^{\circ} \mathrm{C}$ selama 15 menit, kemudian didinginkan sampai suhu \pm 45 $50{ }^{\circ} \mathrm{C}$. Media dasar digunakan dalam pembuatan media pengujian.

\section{Inokulasi Bakteri pada Media Agar Miring}

Bakteri uji diambil dengan jarum ose steril, lalu ditanamkan pada media agar dengan cara digores. Larutan selanjutnya diinkubasi dalam inkubator pada suhu $37^{\circ} \mathrm{C}$ selama 24 jam. Perlakuan yang sama dilakukan pada setiap jenis bakteri uji (Siregar, 2009).

\section{Pembuatan Larutan Standar Mc. Farland}

Larutan $\mathrm{H} 2 \mathrm{SO} 4 \quad 1 \%$ sebanyak 9,95 $\mathrm{mL}$ dicampurkan dengan larutan $\mathrm{BaCl} 22 \mathrm{H} 2 \mathrm{O}$ 1,175\% sebanyak 0,5 $\mathrm{mL}$ dalam Erlenmeyer. Larutan kemudian dikocok sampai terbentuk larutan yang keruh. Kekeruhan ini dipakai sebagai standar kekeruhan suspense bakteri uji (Victor, 1980).

\section{Pembuatan Suspensi Bakteri Uji}

Bakteri uji yang telah diinokulasi dengan jarum ose steril lalu disuspensikan ke dalam tabung berisi $3 \mathrm{~mL}$ larutan $\mathrm{NaCl}$ 0,9\% hingga diperoleh kekeruhan yang sama dengan standar kekeruhan Mc. Farland. Perlakuan yang sama dilakukan pada setiap jenis bakteri uji (Bresson dan Borges, 2004).

\section{Pengujian Aktivitas Antibakter}

Metode yang digunakan dalam penelitian ini adalah metode Kirby-Bauer, yaitu metode difusi dengan cakram kertas. Medium NA dituang ke cawan petri sebanyak $30 \mathrm{ml}$, masing-masing bakteri Staphylococcus aureus, Escherichia coli dan Salmonella typhi sebagai biakan uji, dipipet dari medium larutan NACL $0,9 \%$ ke 3 cawan petri steril masing-masing sebanyak $200 \mu \mathrm{l}$. Cawan petri kemudian digoyang secara perlahan-lahan untuk menyebarkan biakan bakteri secara merata dan didiamkan hingga medium memadat. Masing-masing dari cakram kertas steril dipindahkan secara aseptik menggunakan pinset steril ke konsentrasi yakni 20\%, 40\%, 60\% serta larutan antibiotik (kontrol positif) dan larutan CMC (kontrol negatif) direndam \pm 1 menit. Cakam kertas yang telah direndam dengan ekstrak etanol daun sesewanua, larutan aquades serta antibiotik Ciprofloxacin dipindahlan dengan pinset steril ke medium NA berisi Staphylococcus aureus, Escherichia coli dan Salmonella typhi secara aseptik, kemudian diinkubasi selama 1 x 24 jam dengan suhu $37^{\circ} \mathrm{C}$ (Bresson dan Borges, 2004).

Pengamatan dan Pengukuran

Pengamatan dilakukan setelah 24 jam masa inkubasi. Daerah pada sekitaran cakram menunjukkan kepekaan ekstrak terhadap bakteri yang digunakan sebagai bahan uji yang dinyatakan dengan diameter zona bening. Diameter zona bening diukur menggunakkan jangka sorong. Kemudian zona bening yang diukur dikategorikan kekuatan daya antibakterinya berdasarkan penggelongan (Davis dan Stout, 1971).

\section{Analisis Data}

Diameter zona hambat dari ekstrak etanol daun Sesewanua (Clerodendron squamatum Vahl.) disajikan dalam tabel dan gambar. Penggolongan kekuatan antibakteri dari daya hambat yang diperoleh ekstrak Sesewanua (Clerodendron squamatum Vahl.) digolongkan menurut Davis dan Stout (1971).

\section{Hasil dan Pembahasan}

\section{Ekstraksi Sampe}

Setalah dilakukan maserasi dan remaserasi filtrat yang diperoleh berwarna hijau kehitaman. Filtrat 1, 2 dan 3 dicampurkan menjadi satu, hasil filtrat yang diperoleh sebanyak $750 \mathrm{~mL}$, kemudian dievaporasi menggunakan oven pada suhu $40^{\circ} \mathrm{C}$ selama 1 x 24 jam. Evaporasi bertujuan untuk proses pengentalan larutan dengan cara mendidihkan atau menguapkan pelarut (Poedjiadi, 1994). Setelah dioven dihasilkan ekstrak kental sebanyak 23,3 g berwarna hijau kehitaman.

\section{Pengujian Aktifitas Antibakteri}

Pengukuran diameter zona hambat dilakukan untuk menggolongkan antibakteri. Zona bening yang terdapat disekitar cakram kertas yang diuji menandakan bahwa terjadi aktivitas antibakteri. Adanya zona bening disekitar cakram kertas merupakan daerah difusi dalam mempengaruhi pertumbuhan bakteri. Kekuatan antibakteri diketahui dengan mengukur besarnya diameter zona 
hambat yang terbentuk dari ekstrak yang diuji (Harborne, 1987).

Tabel 1. Diameter Zona Hambat Ekstrak Daun Sesewanua Clerodendron squamatum Vahl. Terhadap Bakteri Staphylococcus aureus, Escherichia coli dan Salmonella typhi

\begin{tabular}{cccc}
\hline \multirow{2}{*}{ Kosentrasi } & \multicolumn{3}{c}{$\begin{array}{c}\text { Diameter Zona Hambat Pertumbuhan } \\
\text { Bakteri (mm) (rata-rata } \pm \text { SD) }\end{array}$} \\
\cline { 2 - 4 } & S. aureus & E. coli & S.typhi \\
\hline $20 \%$ & $14,5 \pm 3,7$ & $8,1 \pm 0,1$ & $9,4 \pm 1,51$ \\
\hline $40 \%$ & $16,91 \pm 0,98$ & $10,8 \pm 1,21$ & $13,23 \pm 1,00$ \\
\hline $60 \%$ & $19,23 \pm 0,11$ & $14,16 \pm 0,20$ & $16,11 \pm 1,91$ \\
\hline Kontrol (+) & $20,3 \pm 0,2$ & $22,2 \pm 0,05$ & $27,26 \pm 1,70$ \\
\hline Kontrol (-) & - & - & - \\
\hline
\end{tabular}

Hasil pengujian dari ekstrak etanol daun sesewanua Clerodendron squamatum Vahl. Terhadap bakteri Staphylococcus aureus, terlihat memiliki zona bening di kosentrasi 20\%, 40\% dan

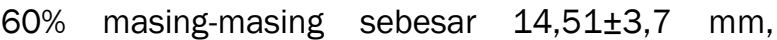
$16,91 \pm 0,98$ dan 19,23 $\pm 0,11$. Kemampuan menghambat dari ekstrak daun sesewanua Clerodendron squamatum Vahl. tampaknya lebih lemah dibandingkan dengan antibiotika ciprofloxacin yaitu sebesar 20,3 $\pm 0,2 \mathrm{~mm}$. Namun dari hasil penelitian menunjukkan bahwa ekstrak daun sesewanua Clerodendron squamatum Vahl. mempunyai aktivitas antibakteri terhadap bakteri Staphylococcus aureus, hal ini terlihat dari zona bening yang terbentuk disekirat cakram. Daya hambat ekstrak etanol daun sesewanua Clerodendron squamatum Vahl. berdasarkan kriteria penggolongan antibakteri dari Davis dan Stout (1971) maka daya antibakteri ekstrak daun sesewanua pada bakteri Staphylococcus aureus dengan konsentrasi ekstrak 20\%, 40\% dan 60\% memiliki kekuatan antibakteri yang termasuk kategori kuat.

Hasil pengujian ekstrak etanol daun sesewanua Clerodendron squamatum Vahl. terhadap bakteri Escherichia coli, terlihat memiliki zona bening dikosentrasi 20\%, 40\% dan 60\% masing-masing sebesar 8,1 $\pm 0,1 \mathrm{~mm}, 10,8 \pm 1,21 \mathrm{~mm}$ dan $14,16 \pm 0,20 \mathrm{~mm}$. Hal ini menunjukkan bahwa estrak daun sesewanua Clerodendron squamatum Vahl. memiliki aktivitas antibakteri dan mampu menghambat pertumbuhan bakteri Escherichia coli. Berdasarkan kriteria penggolongan antibakteri dari Davis dan Stout (1971) maka daya antibakteri ekstrak daun sesewanua pada bakteri terhadap bakteri Escherichia coli, pada kosentrasi 20\% $(8,1 \pm 0,1 \mathrm{~mm})$ memiliki kekuatan antibakteri yang termasuk kategori sedang, sedangkan pada kosentrasi 40\% $(10,8 \pm 1,21)$ dan $60 \%(14,16 \pm 0,20)$ memiliki kekuatan antibakteri kategori kuat. Kamampuan menghambat dari estrak daun sesewanua Clerodendron squamatum Vahl. tampaknya lebih lemah dibandingkan dengan antibiotika ciprofloxacin yaitu sebesar 22,2 $\pm 0,05$ $\mathrm{mm}$.

Hasil pengujian ekstrak etanol daun sesewanua Clerodendron squamatum Vahl. terhadap bakteri Salmonella typhi. Terlihat memiliki zona bening dikosentrasi 20\%, 40\% dan 60\% masing-masing 9,4 $\pm 1,51 \mathrm{~mm}, 13,23 \pm 1,00 \mathrm{~mm}, 16,11 \pm 1,91 \mathrm{~mm}$. Hal ini menunjukkan bahwa bahwa estrak daun sesewanua Clerodendron squamatum Vahl. berdasarkan kriteria penggolongan antibakteri dari Davis dan Stout (1971) maka daya antibakteri ekstrak daun sesewanua pada bakteri Salmonella typhi, pada kosentrasi $20 \%(9,4 \pm 1,51 \mathrm{~mm})$ memiliki kekuatan antibakteri yang termasuk kategori sedang, sedangkan pada kosentrasi $40 \%(13,23 \pm 1,00 \mathrm{~mm})$ dan $60 \%(16,11 \pm 1,91 \mathrm{~mm})$ memiliki antibakteri kategori kuat.

Apabila dibandingkan dengan penelitian lainnya, penelitian yang dilakukan oleh Hermawan (2007) memberikan hasil bahwa ekstrak etanol daun sirih memiliki aktivitas antibakteri terhadap Escherichia coli dan Staphylococcus aureus pada kosentrasi 2,5\%, 5\% dan 10\%. Menurut penelitian Dima (2016) memberikan hasil bahwa ekstrak etanol daun afrika memiliki aktivitas antibakteri terhadap Escherichia coli dan Staphylococcus aureus pada kosentrasi 5\%, 10\%, 20\%, 40\%, dan 80\%. Menurut Azzahra (2019) ekstrak etanol daun alpukat memiliki aktivitas antibakteri terhadap bakteri Staphylococcus aureus dan Salmonella typhi pada kosentrasi 20\%, 40\%, $60 \%$, $80 \%$ dan $100 \%$.

Secara keseluruhan dapat dilihat bahwa semakin tinggi konsentrasi ekstrak yang diberikan, maka semakin besar diameter daerah hambat yang terbentuk. Hal ini sesuai dengan teori, bahwa semakin besar konsentrasi senyawa antimikroba yang diujikan, maka aktivitas antimikroba senyawa tersebut semakin besar (Pelczar \& Chan, 1988).

Berdasarkan pengukuran zona hambat, dapat dilihat bahwa zona hambat bakteri Gram positif (Staphylococcus aureus) lebih besar bila dibandingkan dengan bakteri Gram negativ (Escherichia coli dan Salmonella typhi). Hal ini menunjukkan bahwa ekstrak etanol daun sesewanua lebih peka terhadap bakteri Gram positif. Adanya perbedaan aktivitas ini disebabkan karena perbedaan struktur dan komponen penyusun dinding sel bakteri. Lapisan peptidoglikan pada dinding sel bakteri Gram negatif lebih tipis, sedangkan pada bakteri Gram positif lapisan peptidoglikannya lebih tebal (Radji, 2011).

Pada kontrol positif hasil menunjukan terbentuknya zona bening pada cawan petri dan hasil yang diperoleh lebih besar dari ketiga konsentrasi ekstrak daun sesewanua dimana kontrol positif yang digunakan adalah ciprofloxacin. Hal ini disebabkan karena Ciprofloxacin termasuk dalam golongan antibiotika berspektrum luas yang mampu menghambat pertumbuhan Gram positif dan Gram negativ (Radji, 2011). Kontrol negativ yang digunakan ialah CMC dan hasil yang diperoleh tidak 
memberikan efek antibakteri pada ketiga bakteri uji yang terlihat dengan tidak terbentuknya zona hambat.

Berdasarkan hasil tersebut dapat diketahui bahwa bakteri gram positif dan gram negatif pada konsentrasi ekstrak memiliki sifat dan karakteristik yang berbeda dalam merespon bahan antibakteri. Dinding sel bakteri Gram positif terdiri atas beberapa lapisan peptidoglikan yang membentuk struktur yang tebal dan kaku serta mengandung substansi dinding sel yang disebut asam teikoat, sedangkan dinding sel bakteri Gram negatif hanya terdiri atas satu atau lebih lapisan peptidoglikan yang tipis dan membran di bagian luar lapisan peptidoglikan. Dinding sel bakteri Gram negatif hanya mengandung sedikit lapisan peptidoglikan dan tidak mengandung asam teikoat dan karena hanya mengandung sejumlah kecil peptidoglikan, maka dinding sel bakteri gram negatif lebih rentan terhadap guncangan fisik, seperti pemberian antibiotik atau bahan antibakteri lainnya (Radji, 2011). Hasil penelitian yang diperoleh menunjukan bahwa aktivitas antibakteri ekstrak etanol daun sesewanua lebih kuat dalam menghambat pertumbuhan bakteri Gram positif dibandingkan pertumbuhan bakteri Gram negativ.

\section{Kesimpulan}

Berdasarkan hasil penelitian yang telah dilakukan dapat disimpulkan bahwa Ekstrak etanol daun sesewanua Clerodendron squamatum Vahl. memiliki aktivitas sebagai antibakteri terhadap Staphylococcus aureus, Escherichia coli dan Salmonella typhi. Kosentrasi ekstrak 20\%, 40\% dan $60 \%$ pada bakteri Staphylococcus aureus dan kosentrasi $40 \%$ dan $60 \%$ pada bakteri Escherichia coli dan Salmonella typhi, merupakan konsentrasi yang termasuk dalam golongan kuat, sedangkan pada kosentrasi $20 \%$ pada bakteri Escherichia coli dan Salmonella typhi merupakan kosentrasi yang termasuk dalam golongan sedang

\section{Daftar Pustaka}

Azzahra, F., E. A. Almalik., A. A. Sari. 2019. Uji Aktivitas Antibakteri Dari Ekstrak Etanol Daun Alpukat (Persea Americana Mill.) Terhadap Bakteri Salmonella typhi dan Staphylococcus aureus. Jurnal Kefarmasian Akfarindo. 4 (2) : 5-6

Bresson, W., dan M.T. Borges. 2004. Delivery Methods for Introducing Endophitic Bacteria into Maize. Biocontrol. 49: 315-322.

Brooks, G. F., Carroll, K., Butel, J.S. Jawetz, Melnick, \& Adelberg's Medical Microbiology. Ed ke-26. Philadelphia: McGraw-Hill Company Inc; 2013.

Davis, W. W dan T. R. Stout. 1971. Disc Plate Method of Microbiological Antibiotic assay. Applied Microbiology.

Dima L.R.H, Fatimawali, dan W. A. Lolo, 2016. Uji aktivitas antibakteri ekstrak daun kelor (Moringa oleifera L.) Terhadap bakteri
Escherichia coli dan Staphylococcus aureus. Jurnal Pharmacon. 5(2) : 288.

Harborne, J. B. 1987. Metode Fitokimia Edisi ke2. ITB Press, Bandung.

Hermawan, A. 2007. Pengaruh Ekstrak Etanol Daun Sirih (Piper Betle L.) Terhadap Pertumbuhan Staphylococcus aureus dan Escherichia coli dengan metode difusi disk. Fakultas Kedokteran Hewan, Universitas Airlangga.

Huliselan, Y.M., M.R. Runtuwene, D. S. Wewengkang. 2015. Aktivitas Antioksidan Ekstrak Etanol, Etil Asetat, Dan N-Heksan Dari Daun Sesewanua (Clerodendron squamatum Vahl.). Jurnal Pharmacon. 4(3) : 11-15.

Lay, W.B. 1994. Analisa Mikroba di Laboratorium. Edisi I. PT.Raja Grafindo Persada, Jakarta.

Moot, C.L., W. Bodhi, J. Mongi. 2013. Uji Antipiretik Infusa Daun Sesewanua (Cloredondron squamatum Vahl.) terhadap Kelinci Jantan yang Diinduksi Vanksi DTP HB. Jurnal Pharmacon. 2(3) : 6-8.

Patel, T. dan N. Shrivastava. 2014. Clerodendron and Heathcare. Medicinal and Aromatic Plant Science and Biotechnology. 1: 142 150.

Pelczar, M. J., Chan, E. C. S., 1988. Dasar-Dasar Mikrobiologi. Jakarta: Universitas Indonesia Press.

Poedjiadi, 1994. Dasar-dasar Biokimia. Jakarta: UI-Press.

Radji, M. dan Biomed, M. 2011. Buku Ajar Mikrobiologi Panduan Mahasiswa Farmasi Dan Kedokteran. Jakarta: Buku Kedokteran EGC.

Sangi, M., M. R. Runtuwene, H. E. Simbala, dan V. M. Makang. 2008. Analisis Fitokimia Tumbuhan Obat di Kabupaten Minahasa Utara. Jurnal Kimia. 1(1): 9-10.

Siregar, S.F. 2009. Uji Aktivitas Antibakteri Ekstrak Etanol dan Air Rebusan Kulit Batang Ingul (Toona sinensis M. Roem) Terhadap Beberapa Bakteri. [skripsi]. Fakultas Farmasi USU, Medan.

Vandepitte, V.J., K. Engbaek, P. Rohner, P. Piot, dan C. C. Heuck. 2005. Prosedur Laboratorium Dasar Untuk Bakteriologi Klinis Edisi 2. EGC, Jakarta.

Victor, L. 1980. Antibiotics in Laboratory Test. The Williams and Wilkins Company, USA.

Yudistira, A. 2017. Uji Aktivitas Anti Kanker Payudara Ekstrak Daun Sesewanua (Clerodendron Squmatum Vahl.) Terhadap Sel Kanker Payudara T47d. Jurnal Pharmacon. 6(2): 45-61 